\title{
FILOLOOGIA ON LÄINUD, RAHVUS ON LÄINUD - MIS JÄÄB ALLES?
}

\section{Keel ja Kirjandus 60}

Keele ja Kirjanduse 60. sünnipäeva otsustas toimetus tähistada teemanumbriga „Humanitaarteadused ja rahvus". Siinse ande kirjatükid pakuvad lugejale loodetavasti põnevat arutelu selle üle, kuidas on need kaks asja omavahel seotud ning kas see seos on ajas muutunud. Ajakirja seisukohast on aga viimane küsimus lausa kriitiliselt oluline. Väljaanne asutati ja tema profiil kujundati välja 1958. aastal hoopis teistes oludes. Missugune on eestikeelse, rõhutatult üksnes eesti materjali käsitleva väljaande staatus nüüd, kus viimaste aastakümnete jooksul on muutunud suhtumine rahvuse olemusse ja tähendusse? Võis ette arvata, et juubeli puhul niisuguste teemade ülesvõtmine tekitab ebamugava, ehk isegi piinliku olukorra.

Keele ja Kirjanduse toimimise aluseeldusi iseloomustab hästi küsimuste voor, kus senised peatoimetajad lühidalt kirjutavad, missugusena nad oma ametiajal nägid ajakirja rolli ühiskon- nas. Aksel Tamme, Mart Meri ning Joel Sanga valitsus on langenud erinäolistele perioodidele Eesti ajaloos ning see on tähendanud ka erinevaid pingeid ajakirja töös. Nõukogude Liidu lõpuaastail tuli ikka veel tegelda juba anakronistlikuna mõjuva, kuid jätkuvalt tööka tsensuuriametiga, ${ }^{1}$ noores Eesti Vabariigis kuidagi toime tulla muutuva akadeemilise süsteemiga ja võidelda selle eest, et üha spetsialiseeruvate uurijate tekstid ei muutuks isegi kolleegide jaoks liiga kitsaks. Ometi korduvad vastustes sarnased väljendid: „,eesti asi”, „kutsutud ja seatud teenima eesti rahvast, tema keelt ja kultuuri". Veel 1990. aastate alguses olnuvat iga Keele ja Kirjanduse number kui mitte just laulupidu, siis „väike kokkulaulmine ometi”. Viimase

${ }^{1}$ Täpsemalt on seda kirjeldatud ajakirja 50 aasta juubeli numbris (kust üldse leiab palju Keele ja Kirjanduse ajalukku puutuvat), vt A. T a m m, Riikliku tsensuuri viimased ohked. - Keel ja Kirjandus 2008, nr 1-2, lk 67-74. 
fraasi autor Aksel Tamm manab ühtlasi esile oma eelkäija, ajakirja esimese ja pikaaegse peatoimetaja Olev Jõe vaimu, kahtlustades tema rahulolematust sellega, et rahvuse mõiste niiviisi küsimuse alla seatakse.

Siin on tegu „rahvusliku tähtsuse eeldus ja metaeeldusega”, nagu neid siinses numbris mainib Märt Väljataga (lk 83). Need on Keele ja Kirjanduse tööd saatnud selle loomisest peale. Tundub aga, et ajakirja kaastöölised, eesti keele- ja kirjandusteadlased, folkloristid ja kultuuriuurijad on muutunud nende eelduste suhtes skeptiliseks. Paljud teemanumbri kirjatükid jõuavad humanitaaria ja rahvuse suhteid vaagides välja rahvusteaduste mõiste juurde ega ole sellega kaugeltki rahul. „Tundub, et rahvusteadlastele endile see väga ei meeldi - osalt vist seetõttu, et võõrkeeltesse tõlgitult kõlab see imelikult," märgib Väljataga irooniliselt (lk 84). Marek Tamm vaatleb lühidalt mõiste ajalugu ning arvab, et tänapäeval mõjub see kultuuripoliitilise hoovana taasleitud sõna vanamoeliselt. Eneken Laanes ütleb otsesõnu, et mingil juhul ei tohiks selle kaudu lasta ,juurutada ideed, nagu oleks humanitaarteaduste eesmärk luua rahvuslikku identiteeti" (lk 33) - see olla hoopiski humanitaaria ja rahvuse suhte ähmastamine.

Kas on siis Keele ja Kirjanduse identiteet paratamatult murenemas, kas jälle on tema vundamendist mõni kivi lahti kangutatud? Kahe aasta eest pidasime konverentsi „Filoloogia lagunemine”, millest samuti ilmus teemanumber ( $\mathrm{nr}$ 8-9/2016). Maailmalõpumeeleolulise teemapüstituse ajendas tõdemus, et filoloogia, mis nõukogude süsteemis moodustus keeleteadusest, kirjandusteadusest ja folkloristikast, ei tähenda enam sedasama. (Et see jaotus pole iseenesestmõistetav, märgivad ka siinses numbris Indrek Jääts ja Marleen Metslaid, lk 129.) Need distsipliinid ei kipugi teadusmaastikul enam päris sellises kombinatsioonis esinema ning nagu toonase numbri koostaja Joel Sang eessõnas tõdes, on mõningane killunemine fakt, mis tuleb lihtsalt teatavaks võtta.

Niisiis filoloogia on läinud, rahvus on läinud - mis jääb alles? Mis näoga võib Keel ja Kirjandus nüüd, XXI sajandi teisel kümnendil rääkida eesti asja ajamisest ning kuidas see praktiliselt välja näeb?

Kümne aasta eest, ajakirja 50. sünnipäeval, kaardistas Joel Sang parasjagu Keele ja Kirjanduse ees seisvaid väljakutseid. Tol hetkel oli peamiseks mureks teadusajakirjanduse klassifitseerimine ja avaldamiskoha reputatsioon teadusraha jagajate silmis. Sanga jaoks tähendas see, et tähelepanu pöördub lugeja huvidelt eemale, kirjutaja huvidele, ning see ei tundunud õige. Ta pidas ainuõigeks kangekaelselt jätkata lugeja huvide esikohale seadmist: Keel ja Kirjandus ei tohi olla hermeetiline, peab kaasa rääkima avalikus mõttevahetuses. Ajakirja loetavus oli Sanga keskne huvi terve tema ametiaja jooksul.

Need küsimused pole kadunud, pinge teadusajakirja ja kultuuriajakirja olemuse vahel on Keelele ja Kirjandusele omane olnud kogu aeg. Kuid muutunud on nii teadus- kui ka ajakirjandusmaastik. Väljaandeid on üha rohkem; kirjutamiskohtadest, foorumitest Eestis õieti puudust ei ole. „Võrreldes Soomega on olukord lausa luksuslik," on mõne aasta taguses juubelivestluses leidnud Sirje Olesk. ${ }^{2}$ SA Kultuurilehega liitus äsja seni sõltumatu Müürileht; internetilehekülgede üle ei jõua ammendavat arvestust pidada, kuid suurem hiljutine tulija on Eesti Rahvusringhäälingu kultuuriportaal (kultuur.err.ee). Seda vähem on Keelel ja Kirjandusel mõtet taotleda väga laia ampluaad ja päevakajalisust. Juba mõnda aega ei jõua ajakiri kaugeltki hõlmavalt kajastada isegi Eestis ilmuvat algupärast ilukirjandust, kuigi see oli üks tema algfunktsioone. Pika ilmumistsükliga väljaandel tasub jääda

${ }^{2}$ M. Laak, S. Olesk, Kirjanduse uurimine vajab loolisust ja süvenemist. - Keel ja Kirjandus 2014, nr 10, lk 783. 
ennekõike põhjalike, „aeglaste” materjalikäsitluste juurde. Kasvava argitempoga maailmas muutub süvenemine ju üha suuremaks väärtuseks - aeglane toit, aeglane mood, aga kindlasti ka pikad tekstid.

Temaatilist avardumist tähendab see aga ikkagi, nagu kinnitas filoloogia lagunemise teemaline arutelu. Viimasel ajal olemegi püüdnud ust laiemalt avada kultuuriuuringute suunal, näiteks ilmus 2017. aastal temaatiline topeltnumber eluloouurimusest. Pole see ju rangelt võttes kirjandusuurimus, kuid numbri peamised kaasautorid on just nimelt kirjandusuurijad ja folkloristid. Nagu siinses teemanumbris märgib Tiina Kirss, osutab sõna kultuuriteadused sageli „interdistsiplinaarsete sisendi ja väljundi seoste sagenemisele ehk ajaloolaste, antropoloogide, etnoloogide, folkloristide, kirjandus- ning kunstiteadlaste jt vastastikusele laenamisele" (lk 168). Moesõnana on interdistsiplinaarsus ammu mullune lumi, kuid tegeliku teadustöö argipäeva hakkab see alles tasapisi juurduma. Eriti selgesti tuleb see välja doktoritöödes, mis kajastavad vahetult praegu teadlaste hulgas populaarseid uurimisteemasid: Elle-Mari Talivee väitekirja linnakujutusest varases eesti kirjanduses palusime arvustada ruumiuurimuslikust vaatevinklist ${ }^{3}$; Pikne Kama väitekirja arvustus kannab lausa pealkirja „Kuidas siduda folkloori ja folkloristikat arheoloogiaga?". Ka auhinnad 2017. aasta kaastööde eest osutavad samas suunas: muuhulgas toodi välja lingvistikat ja kultuurilugu kombineeriv poleemika mikroetnonüümi mulk päritolu üle ${ }^{5}$ ning käsitlus, mis uurib Nõukogude

3 K. Kasemets, Liikuvus ja emotsionaalsed juurdumised ajaloolises linnas. Keel ja Kirjandus 2017, nr 10, lk 800-802.

${ }^{4}$ E-H. Västrik, Kuidas siduda folkloori ja folkloristikat arheoloogiaga? - Keel ja Kirjandus 2017, nr 11, lk 886-889.

${ }^{5}$ T. P a e, K. Lu s t, Mulkide nimetuse saamisloost ehk kas mulgid on tõesti rumalad? - Keel ja Kirjandus 2017, nr 6, lk 434-452; repressioonide mõistmist traumana niihästi memuaristikas, ilukirjanduses kui ka filmikunstis ${ }^{6}$.

Kuid ennist oli juttu skepsisest rahvuse suhtes - kas ei kõla viimane teema ikkagi kahtlaselt rahvuslikuna? Nimetatud käsitluse autor Eneken Laanes on siinses teemanumbris kitsa etnilise rahvusidentiteedi suhtes teravalt kriitiline, kuid see ei tähenda, et ta tauniks selle üle arutamist. Vastupidi, ta jõuab välja selleni, et humanitaaria kohuseks on uurida, „kuidas need [rahvuse] kujutlemise viisid tekivad ja muutuvad" (lk 33). Kuigi siinse teemanumbri autorite esteetiline eelistus selles osas, mis raamistikus nende tegevust tõlgendada tuleks, on kohati erinev, ehk lausa vastandlik, tegelevad nad kõik ikkagi mingil moel „eesti asja” uurimisega ning peavad seda vajalikuks. Teemanumbri üks koostajaid Mari Sarv meenutab oma saatesõnas Juri Lotmanile toetudes, et humanitaarteaduste eesmärk on kultuuri enesemõtestamine - iseenesele otsa vaatamine peegelpilti kartmata, isegi kui see on aastate jooksul muutunud. Ning teine koostaja Epp Annus on valmis rehabiliteerima isegi rahvusteadused, öeldes, et see mõiste aitab meenutada teaduse kohust olla laiemas dialoogis ühiskonnas toimuvate protsessidega.

Teadusväljaandeid on samuti juurde tulnud. Sõbralikeks konkurentideks on peale Mäetaguste ja Folklore alates 2008. aastast Methis ning alates 2010. aastast ESUKA. Aastaraamatuid on teisigi, näiteks 2016. aastal vahetas nime ja uuendas imagot Philologia Estonica Tallinnensis, endise nimega Tallinna Ülikooli Eesti Keele ja Kultuuri Insti-

L. Vaba, Rumalad mulgid ehk etümologiseerimise okkaline tee. - Keel ja Kirjandus 2017, nr 7, lk 534-540; K. Lust, T. Pae, E. S a ar, Veel kord mulkide rumalusest. Keel ja Kirjandus 2017, nr 11, lk 862-874.

${ }^{6}$ E. Laanes, Trauma keelde tõlgitud. Kultuurideülesed mäluvormid eesti laagrija küüditamismälestustes. - Keel ja Kirjandus 2017, nr 4, lk 241-257. 
tuudi Toimetised. Kuid need väljaanded (välja arvatud Mäetagused) on vähemalt osaliselt ingliskeelsed. Keele ja Kirjanduse vundament on ikkagi just eestikeelsele „aeglasele mõtlemisele" eluruumi pakkumine. Lisaks põimub see mõtlemine tänases maailmas paratamatult teiskeelse mõtlemisega ning rahulikku süvenemist vajab ka see ümberlülitumine. Tiina Kirss kurdab siinse numbri arvustuses, et mõned muudest mõtteruumidest pärit sõnad jäävad isegi püüdlikult eesti keelde tõlgituna „halliks" ja arusaamatuks. Nii mõtete kui ka sõnade tõlkimine siinsesse konteksti on kindlasti ajakirja üks keskseid teemasid.

Tõsi, juubelinumbris avaldatakse kahtlust isegi selles osas, kas keel pakub püsikindlust ning kas sellesse on mõtet klammerduda. Taas on rangelt keele- lise rahvusidentiteedi suhtes skeptiline Laanes, kes leiab: „Kitsas etniline ja keeleline arusaam eestlaseks olemisest võib olla suures osas Nõukogude okupatsiooni pärand" (lk 36). Tiit Hennoste põrutab küll võimsalt: „Lihtsalt öeldes, kui sureb humanitaarne teaduslik mõtlemine eesti keeles, siis sureb ka eesti rahvus kui kultuurrahvus. Ajaleht ega kooliõpik ei aita midagi” (lk 99) - möönab aga samas artiklis ometi, et mõningaid asju on ,kindlam mõelda [---] inglise keeles" (lk 95).

Ometi loodab Keel ja Kirjandus, et veel kaua väideldakse tema lehekülgedel eesti keeles selle üle, kas eestlus on konstruktsioon või mitte ning kas eesti keeles mõtlemine on vajalik või mitte.

JOHANNA ROSS 